\title{
ПРОГРАММА ВНЕШНЕТОРГОВЫХ ЗОН США: НАЦИОНАЛЬНАЯ КОНЦЕПЦИЯ ИНСТИТУТА ОСОБОЙ ЭКОНОМИЧЕСКОЙ ЗОНЫ
}

\begin{abstract}
Аннотация. Автор подробно рассматривает национальную концепцию особой экономической зоны (внешнеторговой зоны) в США. Особое внимание уделяется предпосылкам разработки и внедрению на государственном уровне единообразной модели особых экономических зон. Анализируются основные факторы, повлиявшие на изменение содержания концепции и приведшие к резкому росту популярности внешнеторговых зон среди участников внешнеторговой деятельности. Автор охарактеризовал как нормативный, так и институциональный механизмы реализации концепции особой экономической зоны, уделив важное внимание так называемой политике нейтралитета Таможенно-пограничной службы США. Наравне с общенаучными и специальными методами научного познания был использован сравнительно-правовой метод, позволяющий проводить как синхронное сравнение, так и многоуровневое: нормативное и функциональное. Основными выводами проведенного исследования являются следующие. Успешное функционирование Программы внешнеторговых зон США объясняется простотой процедуры по созданию внешнеторговых зон. Ключевым фактором эффективности института внешнеторговых зон в США является внимание законодательного органа власти. Ежегодные слушания в Конгрессе по этому вопросу позволяют законодателям оперативно реагировать на изменения в мировой экономике, внешней и внутренней торговле, а также занятости населения.

Ключевые слова: особая экономическая зона, внешнеторговая зона, подзона, международная торговля, нормативный механизм, институциональный механизм, управление, таможенные пошлины, государственный бюджет, занятость.

Review. The author discusses the national concept of a special economic zone (foreign-trade zone) in the USA. Special attention is paid to the preconditions of development and implementation of a uniform model of special economic zones on the state level. The author analyzes the main factors which have influenced the change of the concept and lead to the dramatic increase of popularity of foreign-trade zones among the participants of foreign-trade activity. The author characterizes both normative and institutional mechanisms of implementation of the concept of a special economic zone, paying special attention to the so-called policy of neutrality of the US Customs and Border Service. Along with the general and special scientific methods of cognition the author applies the comparative-legal method which allows the author to carry out both a synchronous and a multilayer comparison: normative and functional. The author concludes that a successful functioning of the foreign-trade zones program in the USA can be explained by the simplicity of the procedure of their creation. The key factor of the efficiency of foreign-trade zones in the USA is the attention of the legislative authority. The annual congressional hearings of this problem allow the legislators to efficiently react to the changes in the world economy, the external and internal trade, and the population employment.
\end{abstract}

Keywords: management, institutional mechanism, normative mechanism, international trade, subzone, foreign-trade zone, special economic zone, custom duties, national budget, employment.

$\mathrm{B}$ Российской Федерации институт особых экономических зон (далее - ОЭ3) существует уже более 10 лет, но, несмотря на то, что законодательная база постоянно совершенствуется и активно создаются новые ОЭЗ, пока что трудно говорить об успехе их функционирования. На наш взгляд, имеющийся мировой опыт позволяет выбрать необходимое направление в правовом регулировании этого института с учетом особенностей правовой системы, формы государственного правления и состояния экономики РФ.

В отличие от экономической науки, в юридической науке проблема эффективного функционирования особых экономических зон исследована мало. Так, К.С. Свинцова, М.В. Батыров и А.А. Гариб исследовали административно-правовое регулирование $0 Э 3$ в РФ. Финансово-правовые аспекты регулирования ЭОЗ были подробно исследованы в работах Д.А. Савосик и Е.В. Безиковой. Налоговые льготы и преимущества, предусматриваемые в 0ЭЗ, подробно рассматривались С.А. Рыбаковым и Н.А. Орловой. ОЭЗ как механизм эффективного развития международной инвестиционной и инновационной деятельности детально исследовались П.В. Павловым.

В настоящей статье мы охарактеризуем особенности правового регулирования ОЭЗ в США, поскольку этот институт имеет более чем семидесятилетнюю историю существования, начиная со времен Великой депрессии, когда экономика США переживала не лучшие времена. Опыт использования данного института, в том числе для развития экономики, стоит пристального внимания научного сообщества РФ. Для достижения указанной цели наравне с общенаучными и специальными методами научного познания необходимо использовать 
сравнительно-правовой метод, позволяющий проводить как синхронное сравнение, так и многоуровневое: нормативное и функциональное.

В законодательстве США для обозначения ОЭЗ используется термин внешнеторговые зоны (далее - ВТЗ). Терминологическое разнообразие, встречаемое в литературе и нормативно-правовых актах, можно объяснить множеством государств, где расположены 0Э3, и их конкретными типами. В государствах с развивающейся экономикой, ориентированных на экспорт, они, как правило, носят название экспортно-производственных зон (export processing zones). В Китае они носят название «особых экономических зон», в Ирландии «свободных промышленных зон» или «зон свободного экспорта», в Иордании и Египте - «квалифицированные промышленные зоны», в Объединенных Арабских Эмиратах - «свободные зоны», в Республике Корея - «зоны обработки беспошлинного экспорта». В международно-правовых соглашениях для обозначения ОЭЗ используется термин «зоны свободной торговли» (далее - ЗСТ).

Для ОЭЗ характерны ограниченный доступ (как правило, это огражденная территория) и наличие индустриальных парков с производственными мощностями и соответствующей инфраструктурой. ОЭЗ обычно располагаются рядом с морскими/речными портами, аэропортами или транспортно-логистическими центрами [1].

Во всем мире ОЭЗ схожи в принципах функционирования. Отличия касаются размеров, экономических целей, физических характеристик, государственных стимулов и конечного назначения товаров. ОЭЗ могут быть представлены как существенные части промышленного сектора государства и занимать большие географические территории, как в Китае, или это могут быть маленькие анклавы, занятые несколькими предприятиями. В развивающихся странах со слабо развитой инфраструктурой они могут быть представлены промышленными комплексами городского типа, которые обеспечены жильем, продовольствием, банковскими учреждениями и транспортом. С другой стороны, в развитых странах с хорошо развитой инфраструктурой ОЭЗ представлены как комплексы, предназначенные исключительно для производства и транспортирования. В США, вместо того, чтобы привязывать создание ВТЗ к специфическим географическим условиям (например, наличие порта), такой режим быстро и упрощенно предоставляется компании, где бы она ни находилась. Всем зонам присущи наличие упрощенных таможенных процедур и исключения или отсрочка тарифных и количественных ограничений для продукции, находящейся в пределах зоны. Развивающимся странам присущи также такие методы стимулирования, как субсидии, более «гибкие» положения трудового законодательства и дополнительные налоговые льготы, однако использование субсидий в некоторых случаях нарушает обязательства государств-участников ВТО. Кроме того, использование более «гибких» трудовых стандартов противоречит минимальным трудовым стандартам, установленным Международной организации труда и Организации экономического сотрудничества и развития [2]. Существует следующая закономерность: государство с развивающейся экономикой обычно производит в ОЭЗ товары на экспорт, но как только его экономика становится развитой (растет индекс потребления внутри страны), существенная часть произведенных в $0 Э 3$ товаров начинает усиленно потребляться (импортироваться).

Рост $0 Э 3$ является результатом влияния совокупности факторов, включая модель, выдержавшую проверку временем, международный механизм, обеспечивающий создание 0Э3, привлекательных для зарубежных инвесторов, а также технологический прогресс, влияющий на глобализацию производства.

Рост современных ОЭЗ начался в 1959 г. с эксперимента по перепрофилированию аэропорта в г.Шеннон (Ирландия). Задуманная первоначально как программа по созданию рабочих мест, она была настолько успешна, что Организация ООН по промышленному развитию (ЮНИдО) подготовила руководство по организации таких зон и создала несколько миссий по учреждению подобных зон в некоторых государствах мира. Позднее Всемирная ассоциация зон свободной торговли (World Export Processing Zones Association (WEPZA)), первоначально созданная ЮНИД0, отделилась в частную некоммерческую организацию, поддерживающую успешное развитие подобных зон по всему миру.

Правительство США помогало распространять концепцию ЗСТ в период 1983-1995 гг., путем предоставления займов и мер инвестиционной поддержки через пять правительственных агентств: Агентство США по международному развитию (the U.S. Agency for International Development (USAID)); Коропрацию частных зарубежных инвестиций (the Overseas Private Investment Corporation (OPIC)); Экспортно-импортный банк (the Export-Import Bank); Государственный департамент (the Department of State) и Министерство торговли (the Department of Commerce) [3].

Развитие технологий, включая всемирные коммуникационные компьютерные сети, распространение контейнерных морских и других видов перевозки привело к увеличению и распространению ЗСТ во всем мире. Другие факторы, влияющие на распространение ЗСТ, как отмечают в Органи- 


\section{Административное и муниципальное право 11 (95) • 2015}

зации экономического сотрудничества и развития [2], включают в себя экспортно-ориентированный и ориентированный на привлечение зарубежных инвестиций рост экономики, перемещение производства трудоемких предприятий из развитых в развивающиеся страны, рост международного разделения труда и распространение глобальных производственных сетей.

Программа внешнеторговых зон США была учреждена Федеральным актом о внешнеторговых зонах 1934 г. в период Великой депрессии. Целью данной программы было стимулирование торговли, которая испытывала на тот момент негативный эффект от действия Федерального акта о тарифах Смут-Хоули 1930 г. (Smoot-Hawley Tariff Act of 1930), поднявшего тарифы на импортируемые товары до 53\%. [4]. В рамках реализации Программы был учрежден Совет по ВТЗ, которому были переданы полномочия по приему и утверждению заявок на получение статуса ВТЗ. Федеральный акт о ВТЗ, небольшой по объему (всего 6 страниц текста), предоставил каждому из 53 портов США минимум по одной ВТЗ и утвердил технические условия и стандарты для каждой зоны, виды деятельности, которые можно осуществлять в ВТЗ, особенности применения федерального законодательства, требования к делопроизводству и эксплуатации ВТЗ.

Поначалу Программа ВТЗ не пользовалась популярностью. До 1959 г. количество ВТЗ не увеличивалось и их задействованность была весьма низкой. Но сочетание как внутренних, так и внешних факторов привело к резкому росту популярности ВТЗ в торговых отношениях.

К внутренним факторам следует отнести, прежде всего, внесение изменений в Программу, касающихся разрешения осуществления производственных процессов. Федеральный акт о ВТЗ в редакции 1934 года запрещал осуществление производственных процессов в ВТЗ из-за опасений, что будут импортироваться более дешевые комплектующие, чем те, которые производятся местными производителями, что причинит последним убытки. Однако такая модель, как ни странно, не привлекла много резидентов. Тогда в 1950 г. Конгресс принял поправку о допустимости осуществления производственных процессов в ВТЗ. Двумя годами позже, в 1952 г., Совет по ВТЗ в рамках толкования данной поправки издал новый Регламент о ВТЗ, позволяющий регистрировать на территории ВТЗ производственные имущественные комплексы компаний, что привлекло к появлению большого количества резидентов. Способствованию роста ВТЗ послужили два административных решения Казначейства США 1980 и 1982 гг., которое пояснило, что производители не должны платить ни НДС, ни брокерские или транспортные сборы на импортируемые товары [5].
Внешние факторы, повлиявшие на популярность ВТЗ среди американских или зарубежных корпораций, включали: а) возросшую международную ценовую конкуренцию, заставившую американские компании искать пути к снижению издержек, б) возросшую осведомленность предпринимателей в способах экономии затрат путем использования ЗСТ; и в) научно-технический прогресс, сделавший возможным международное торговое сотрудничество [6].

На сегодняшний день основная деятельность, которая осуществляется в 293 ВТЗ, представлена разнообразными производственными операциями [7]. Зона может быть учреждена прямо на территории предприятия и использоваться для производственной или складской деятельности.

В каждом штате есть, как минимум, одна ВТЗ, поэтому все штаты вовлечены в Программу ВТЗ, которая позволяет производить продукцию, используя собственные (58\% или \$429 млрд.) и импортируемые (42\% или \$304 млрд.) комплектующие [8].

0 важности Программы внешнеторговых зон США для экономического развития государства свидетельствует постоянный на протяжении последних 70 лет интерес членов Конгресса, проявляющийся в регулярных слушаниях и соответствующем оперативном корректировании законодательства. Как отмечается в отчете Федерации американских ученых (The Federation of American Scientists), предоставленном для слушаний в Конгрессе 12 ноября 2013 года, Программа внешнеторговых зон США усиливает конкурентоспособность предпринимателей, поддерживает занятость и влияет на тарифные доходы [9].

С 1993 по 2012 гг. общее количество (в денежном эквиваленте) сырья и комплектующих, используемых в ВТЗ как местного так и зарубежного происхождения, увеличилась более чем в 6 раз (со 104 до 732 млрд долларов). В значительной мере это увеличение было вызвано увеличением стоимости сырой нефти за этот период. Значительная часть сырья и комплектующих в ВТЗ имеет местное происхождение, равно как и готовая продукция потребляется в основном на внутреннем рынке США. Это отличает внешнеторговые зоны США от ЗСТ в развивающихся странах, которые являются экспортоориентированными.

Уровень занятости в ВТЗ остается на протяжении последних 20 лет относительно одинаковым. Он немного вырос в начале 1990-х гг., когда значительное количество трудоемких автомобильных производств переместилось в ВТЗ, и испытал приблизительно такой же незначительный спад после 1997 г. из-за популярности ВТЗ у нефтеперерабатывающих компаний, производящих капиталоемкие 
бензин, керосин, дизельное и авиационное топливо (хранение которых не облагалось пошлиной) и продукты нефтепереработки (к которым применяется «перевернутый» тариф). Поэтому импортеры могут беспошлинно ввозить готовые нефтехимические продукты вместо ввоза сырой нефти с пошлиной 5.25 или 10.5 центов за баррель. Но тарифы на импорт бензина и другие нефтепродуктов выше, чем тарифы на импорт сырой нефти, следовательно уплачивается тариф за часть сырой нефти, используемой для производства такой продукции. Для автомобильных комплектующих, поступающих из стран, с которыми нет соглашения о свободной торговле, тарифы выше, чем на готовые автомобили.

Основу импорта в ВТЗ закладывает сырая нефть. Так, в 2012 году 72\% импортируемых товаров составила сырая нефть, автомобильные комплектующие - 7\%, в остальном сегменте в 21\% лидирующие позиции занимает бытовая электроника и оборудование. Доминирование нефтяных компаний в ВТЗ объясняется преимуществами «перевернутого» тарифа на нефтехимические продукты [9].

Правовую основу функционирования ВТЗ составляют Федеральный акт о ВТЗ 1934 г. и два регламента - Регламент Совета по ВТЗ и Регламент Таможенно-пограничной службы США. Отдельные положения закреплены также в других законах и регламентах. Рассмотрим подробнее нормативноправовую базу.

Федеральный акт о ВТЗ 1934 г. - основной нормативно-правовой акт, учредивший институт ВТЗ и включенный в Кодекс США (United States Code, 19 U.S.C. 81a-81u) [10]. Данный закон неоднократно дополнялся и на сегодняшний день содержит общие положения о порядке учреждения и управления зонами, а также о видах деятельности, которые могут осуществляться резидентами. Каждый учредитель, оператор и большинство пользователей должны иметь копию этого закона в последней редакции.

Федеральный закон о внешнеторговых зонах 1934 г., формируя главу 1А титула 19 Кодекса США, состоит из 21 параграфа: §81а Определения; §81b Создание зон; §81с Освобождение от уплаты таможенных сборов с ввозимых в торговую зону товаров; §81d Таможенники и охранники; §81е Входящие и выходящие суда; прибрежная торговля; §81f Заявка на создание и расширение зоны; §81g Утверждение заявки; §81h Правила и положения; §81i-§81j Сотрудничество Совета с федеральными и местными властями; §81k Соглашения касательно использования имущества; 8811 Предоставляемые и поддерживаемые услуги; §81m Разрешение на использование зоны третьими лицами; §81n
Функционирование ВТЗ в государственных и общественных интересах; расходы на таможенные услуги; §81o Резиденты зоны; §81р Бухгалтерия и документооборот; §81q Получение гранта управляющей компанией; §81r Отзыв гранта; §81s Правонарушения; §81t Автономность положений закона о ВТЗ; §81u Право изменять, вносить поправки или отмена положений [11].

Регламент Совета по ВТЗ содержит руководство с детальным описанием процедур по учреждению и изменению ВТЗ; определяет порядок управления и администрирования учредителем и операторами; а также порядок осуществления полномочий Советом. Регламент Совета по ВТЗ о внешнеторговых зонах в редакции 2012 г. включен в свод федеральных нормативных актов США (Code of Federal Regulations, 15 CFR Part 400 - FTZ Regulations) [12] и состоит из преамбулы и 8 подразделов: A - Область применения, определения и полномочия; В - Возможность создания зоны; ограничения и запреты для управляющей компании; C - Заявки на назначение и изменение управляющей компании; D - Процедуры по оцениванию и утверждению заявок управляющих компаний; E - Деятельность в ВТЗ и административные требования; F - Делопроизводство, отчеты, уведомления, слушания и информация; G - Штрафы и апелляции в Совет [11, с. 468].

Федеральный закон о ВТЗ 1932 г., Гармонизированный тариф США, кодифицированный в титуле 19 Кодекса США, положения §541-552 титула 18 Кодекса США, отображающие положения Федерального закона о тарифах 1930 г., составляют большую часть таможенно-пограничного законодательства. Особое место занимает Регламент Таможенно-пограничной службы США о внешнеторговых зонах, включенный в свод федеральных нормативных актов США [13]. Любой товар, за исключением запрещенного законом, может ввозиться и складироваться в ВТЗ, а также при некоторых условиях перерабатываться, не подпадая под действие таможенно-пограничного законодательства (19 U.S.C. §81c(a)).

За исключением некоторых случаев, нормы таможенно-пограничного законодательства не действуют в ВТЗ. Однако они применяются к товарам, перемещаемым по таможенной территории до ввоза или после вывоза из зоны. Они также применяются к товару, запрещенному в ВТЗ, транспортным средствам и воздушным судам, попадающим или покидающим зону, а также к товару, который ввезен в зону для целей, не предусмотренных Федеральным актом о ВT3 (15 CFR 400.1(c)).

В соответствии с общими правилами, необходимыми для защиты доходов и обеспечения соблюдения Федерального закона о ВТЗ, тамо- 


\section{Административное и муниципальное право 11 (95) • 2015}

женно-пограничное законодательство требует от операторов ведения определенного учета и предоставления соответствующих отчетов (19 U.S.C. §66, 81h, 81p, 1624).

Поскольку Федеральный закон о ВТЗ 1932 г. при определенных обстоятельствах исключает действие таможенно-пограничного законодательства, большинство иных федеральных законов, в частности, в сфере здравоохранения, миграции, труда, социального обеспечения и налогообложения прибыли - в ВТЗ действуют. Большинство законов, регулирующих экспорт, применяются Таможенно-пограничной службой в ВТЗ (например, 15 CFR 772 - Регламент администрирования экспорта и 22 CFR 121-130 - Регламент международной торговли товарами и услугами военного назначения). Более того, разнообразные федеральные регламенты могут применяться в ВТ3, например, когда речь идет об определенных группах товаров или деятельности в отношении товаров.

Совет по ВТЗ обязан сотрудничать с Таможенно-пограничной службой США, а также с другими федеральными службами, имеющими юрисдикцию в портах ввоза (19 U.S.C. §81i, 15 CFR 400.12(e)), такими как Бюро по налогообложению и торговле табаком и алкоголем (Alcohol \& Tobacco Tax and Trade Bureau (ТTB)), Федеральная комиссия по связи (Federal Communications Commission (FCC)), Агентство по охране окружающей среды США (Environmental Protection Agency (ЕРA)), Управление по санитарному надзору за качеством пищевых продуктов и медикаментов (Food and Drug Administration (FDA)), Министерство сельского хозяйства США (Department of Agriculture (USDA)), Служба охраны рыбных ресурсов и диких животных США (Fish and Wildlife Service (USF\&W)). Эти службы действуют в рамках утвержденных регламентов, постановлений, инструкций, которые прямо касаются деятельности ВТЗ.

Законодательство штатов и муниципалитетов имеет силу в тех случаях, когда не применяется федеральное законодательство или конституция. Совет по ВТЗ сотрудничает с властями штатов, округов и муниципалитетов, где размещена зона, при осуществлении ими своих полицейских, санитарных и других полномочий в отношении ВТЗ (19 U.S.C. §81i, 15 CFR 400.41). Особое внимание следует обратить на следующие положения.

Торговая оговорка Конституции США (Commerce Clause of the Constitution) - Конституция оставляет за Конгрессом право регулировать международную торговлю [14] и запрещает штатам взимать налоги с экспорта и импорта [15]. Законодательство штатов не применяется в зонах в той степени, что они будут противоречить Конституции США и федеральному законодательству.
Федеральный акт о ВТЗ прямо запрещает применение штатами адвалорных пошлин к импортируемому движимому имуществу, которое хранится или подвергается обработке в ВТЗ, а также к движимому имуществу, произведенному в США и находящемуся в зоне для дальнейшего экспорта в виде сырья или готовой продукции (19 §81o(e)) (см., например, дело Deer Park Independent School District v. Harris County Appraisal Dist. 1998) [16].

К источникам правового регулирования необходимо отнести налоговое законодательство штатов - некоторые штаты предоставляют определенные льготы резидентам ВТЗ, а также имеют право взимать адвалорные пошлины на движимое имущество; разрешительное законодательство - Регламент Совета по ВТЗ требует наличия в каждом штате специального закона, наделяющего правительство штата правом подавать заявки о создании ВТ3 в Совет по ВТ3 (15 CFR 400.22(b) and (c)).

Особо следует отметить такой нормативный акт, как график работы BT3 (Grantee Schedules). Учредитель ВТЗ обязан предоставить в Совет по ВТЗ для рассмотрения и утверждения график работы ВТЗ. Расписание должно быть доступно для ознакомления в офисе учредителя и оператора. Все лица, посещающие ВТЗ по любой причине, обязаны соблюдать график работы ВТЗ в дополнение к применяемым правительственным регламентам. Требования к графику работы ВТЗ содержатся в 15 CFR 400.42(b).

Институциональный механизм внешнеторговых зон представлен рядом органов государственной власти, наделенных соответствующими полномочиями.

Так, Совет по ВТЗ наделен компетенцией учреждения, организации деятельности и управления зонами в соответствии с Федеральным законом о ВТЗ 1932 г. Кроме того, полномочия Совета по ВТЗ распространяются и на решение вопросов, связанных с товарами, сырьем, комплектующими и видами деятельности. Таможенно-пограничная служба США несет ответственность за исполнение Федерального закона о тарифе и другого законодательства во внешнеторговых зонах. Рассмотрим подробнее правовой статус компетентных органов.

В Совет по ВТЗ входит Министр торговли, являющийся председателем, Исполнительный директор и Секретарь Казначейства (19 U.S.C. §81a(b)). В соответствии с 15 CFR 400.11 Совет по ВТЗ имеет следующие полномочия: 1) разработка правил и положений; 2) предоставление полномочий учредителям по созданию ВТЗ и подзон, утверждение изменений в существующей зоне; 3) учреждение видов производственной деятельности в ВТЗ и подзонах в соответствии с пунктом D раздела 15 CFR 400; 4) издание предписаний, требующих 
внимания Совета в соответствии с 15 CFR 400; 5) рассмотрение жалоб по некоторым решениям заместителя Министра торговли по импорту или Исполнительного директора; 6) инспектирование строений, проверка деятельности и учетных записей учредителей и операторов зон; 7) истребование докладов учредителей о деятельности в ВТЗ; 8) представление ежегодных докладов Конгрессу; 9) ограничение или запрет определенных видов деятельности в ВТ3; 10) назначение штрафов за нарушение Федерального закона о ВТЗ; 11) отзыв полномочий учредителей; 12) определение, в соответствующих случаях, факта - представляет ли (будет представлять) определенная деятельность в ВТЗ государственный (общественный) интерес или, наоборот, причинит ущерб этим интересам, безопасности или здоровью граждан.

В соответствии с §81ј титула 19 Кодекса США Президент США уполномочен издавать указы о содействии федеральных агентств друг другу в проведении расследований и исполнении полномочий. В исполнение этого положения, 18 июля 1935 года был издан указ президента 7104, предписывающий всем федеральным исполнительным органам оказывать содействие Совету по ВТЗ в исполнении его полномочий по учреждению и организации деятельности ВТЗ, а также в проведении расследований, путем предоставления необходимых документов и информации, сотрудников, экспертов и других специалистов.

Министр торговли и Секретарь Казначейства редко осуществляют полномочия членов Совета по ВТЗ лично. Вместо этого они уполномочены назначать своих заместителей, которые действуют вместо них в официальном статусе (15 CFR 400.11(c)) и формируют Комитет заместителей (Committee of Alternates). Заседания Совета проводятся периодически по необходимости для решения вопросов политики, связанные с Советом. Однако решение текущих вопросов проводится путем обмена корреспонденцией заместителей.

Исполнительный директор (Executive Secretary) Совета по ВТЗ назначается Министром торговли для руководства решением текущих вопросов. Обязанности Исполнительного директора содержатся в 15CFR 400.4.

Директор порта (Port Director) выступает в качестве местного представителя Совета по ВТЗ. Он может приглашать местных представителей других правительственных агентств для консультаций по вопросам, связанным с созданием, управлением и администрированием BT3 (15 CFR 400.41; 19 CFR 146.2). Директор порта несет ответственность за осуществление общего контроля над зоной, деятельностью учредителя, оператора и пользователей, а также за информирование Совета по ВТЗ об особых ситуациях. Директор порта консультируется и дает рекомендации Совету по ВТЗ о любых изменениях границ зоны по запросу учредителя или сотрудников Совета (15 CFR 400.26(a) (2)). Одобрение Таможенно-пограничной службы США всегда необходимо для изменения условий и должно быть отображено в комментариях Директора порта. Он не имеет властных полномочий как местный представитель Совета по ВТЗ, кроме тех, которые предоставлены ему в соответствии с ордером Совета. Обычно Совет по ВТЗ полагается на рекомендации Директора порта по решению местных вопросов.

Таможенно-пограничная служба США (U.S. Customs and Border Protection, далее - ТПС) выполняет большинство функций и обязанностей Министра торговли в соответствии с Федеральным актом о ВТЗ. Они включают в себя подготовку и имплементацию правил и регламентов, утверждаемых Секретарем Казначейства согласно Федеральному акту о ВТ3 (19 U.S.C. §81c, §81e, §81o(b)), а также назначение персонала ТПС, необходимого для выполнения функций, предусмотренных 19 U.S.C. §81d. Однако ТПС не представляет Секретаря Казначейства в вопросах ВТЗ, которые касаются (1) определения стратегии развития или (2) исполнения полномочий других агентств Министерства финансов, не делегированных Таможенно-пограничной службе США (например, Бюро по налогообложению и торговле табаком и алкоголем (Alcohol \& Tobacco Tax and Trade Bureau (TTB)) или Налоговой службы США (Internal Revenue Service (IRS)).

Основная задача ТПС - контроль над движением грузов в зону и из нее, защита доходов государства и обеспечение соответствия деятельности в зонах законодательству о ВТЗ.

Политика нейтралитета ТПС основывается на ее особом статусе - это правоприменительный орган власти, который не может поощрять или препятствовать созданию или использованию зон. Сотрудники ТПС не уполномочены консультировать по вопросам преимуществ в использовании разных зон или использования зон вместо других административных механизмов на таможенной территории США.

Комиссар Таможенно-пограничной службы США (The Commissioner of СВР) согласно делегированным полномочиям от Министра финансов назначает персонал ТПС для защиты доходов и контроля над ввозом товаров на таможенную территорию США (19 U.S.C. §81d). Расходы по созданию дополнительных постов ТПС возлагаются, согласно Федеральному акту о ВТЗ, на оператора зоны (19 U.S.C. §81n). До недавнего времени ТПС обеспечивала доходы от ВТЗ путем осуществления 


\section{Административное и муниципальное право 11 (95) • 2015}

физического контроля движения товара в зону и из нее, а также операций по переработке на территории зоны. На сегодняшний день ТПС использует метод аудиторской проверки, которая заключается в следующем: 1) определение идентичности и характера товара до или после его хранения в зоне, поэтому ответственность оператора за товар может быть достоверно определена; 2) выдача предварительного разрешения оператору для ввоза, вывоза и любой обработки в зоне; 3) презумпция ответственности оператора за товар в зоне, в том числе физический надзор, безопасность, ведение документации, соблюдение условий хранения и обработки (количество товара определяется совместно оператором и перевозчиком); 4) осуществление ТПС аудита и проверки соответствия для подтверждения выполнения оператором требований законодательства по осуществлению контроля в ВТЗ и ведению учетных записей; 5) адекватное обеспечение оператором возможной неустойки при невыполнении обязательств по осуществлению контроля; 6) полномочия ТПС по приостановлению активного статуса оператора на срок не более 90 дней или аналогичные полномочия Совета по ВТЗ по продлению такового на более длительный срок в случае несоответствия его деятельности законодательству о BT3 (19 CFR 146.82). Директор порта может в любое время рекомендовать Совету по ВТЗ приостановить функционирование BT3 по причине умышленных и регулярных нарушений Федерального акта о ВТ3 (19 CFR 146.83).

Пределы и природа контроля ТПС в ВТЗ предусмотрены в 19 U.S.C. §81a-u, 19 CFR 1646a, 19 CFR 161.2, 19 CFR 146. Директор порта может уточнить, назначить или запросить у ТПС проведение проверки любой операции или процедуры в ВТЗ. ТПС осуществляет контроль путем проверки документации, инвентаризации товара, проверки на соответствие определенных операций или процедур, аудита бухгалтерской документации, проверки условий хранения и безопасности (19 CFR 146.3).

Иммиграционная и таможенная полиция США (Homeland Security's Bureau of Immigration and Customs Enforcement (ICE)) сотрудничает на началах добровольного партнерства с резидентами ВТЗ в противодействии незаконному трудоустройству. В ВТЗ применяются то же миграционное и трудовое законодательство, что и на остальной территории США.

Поскольку Совет по ВТЗ и другие федеральные агентства обязаны сотрудничать (19 U.S.C. §81i; 19 U.S.C. §81j), операторам и пользователям приходится сталкиваться с другими компетентными органами, чья юрисдикция распространяется на товары или деятельность в ВТЗ.
В результате проведенного исследования можно сделать следующие выводы. Во-первых, становление института внешнеторговых зон в США происходило в русле разработанной государственной концепции, предусматривающей как нормативный, так и институциональный механизм. Нормативный механизм состоит из специального федерального закона и подзаконного нормативного акта - Регламента, который содержит руководство с детальным описанием процедур по учреждению и изменению ВТЗ; определяет порядок управления и администрирования учредителем и операторами; а также порядок осуществления полномочий Советом по ВТЗ. Кроме того, нормативный механизм содержит нормы как таможенного, так и внешнеторгового законодательства. Институциональный механизм представлен Советом по ВТЗ, который состоит из Министра торговли и Секретаря Казначейства, делегирующих свои полномочия Комитету своих заместителей. Этот Комитет возглавляется Исполнительным директором, назначаемым Министром торговли для руководства решением текущих вопросов. Оперативное управление каждой зоной осуществляется специально назначенным директором порта, имеющим статус местного представителя Совета по ВТЗ. Директор порта не имеет властных полномочий кроме тех, которые предоставлены ему в соответствии с ордером Совета. Таможенно-пограничная служба США включена в институциональный механизм постольку, поскольку исполняет свои полномочия, предусмотренные законом.

Во-вторых, успешное функционирование Программы ВТЗ объясняется как простотой процедур по созданию ВТЗ, так и исполнением указа 7104 Президента США, предписывающего всем федеральным исполнительным органам оказывать содействие Совету по ВТЗ в исполнении его полномочий по учреждению и организации деятельности ВТ3, а также в проведении расследований путем предоставления необходимых документов и информации, сотрудников, экспертов и других специалистов.

И, наконец, ключевым фактором эффективности института ВТЗ в США является внимание законодательного органа власти. Ежегодные слушания в Конгрессе по этому вопросу позволяют законодателям оперативно реагировать на изменения в мировой экономике, внешней и внутренней торговле, а также занятости населения.

На наш взгляд, изучение многолетнего опыта существования Программы внешнеторговых зон в США может дать полезные знания для развития российской национальной концепции подобных особых экономических зон, что будет способствовать улучшению правовой системы и экономики РФ. 
Библиография:

1. Горян Э.В. Становление института подзоны особой экономической зоны в США // Административное и муниципальное право. - 2015.-№ 10.-C.1029-1038. - C. 1030. DOI: 10.7256/1999-2807.2015.10.16480

2. Engman M., Onodera O., Pinali E. Export Processing Zones: Past and Future Role in Trade and Development // OECD Trade Policy Papers 53, OECD Publishing [Электронный ресурс]. - Режим доступа: https://ideas.repec.org/p/oec/ traaab/53-en.html (дата обращения: 20.10.2015)

3. Diamond W.H., Diamond D.B., Tax-Free Trade Zones of the World, Unz \& Co., 1997. - P.33.

4. $\quad$ Yarbrough B.V., Yarbrough R.M. The World Economy: Trade and Finance.-Harcourt Brace, 1991. - P. 368.

5. GAO, Foreign-Trade Zones Growth Primarily Benefits Users Who Import for Domestic Commerce, GAO/GGD 84-52, March 2, 1984, p. 12 [Электронный ресурс]. - Режим доступа: http://gao.justia.com/department-of-commerce/1984/3/ foreign-trade-zone-growth-primarily-benefits-users-who-import-for-domestic-commerce-ggd-84-52/GGD-84-52-fullreport.pdf (дата обращения-20.10.2015)

6. U.S. Congress, House, Committee on Government Operations, Foreign-Trade Zones (FTZ) Program Needs Restructuring, House Report 101-363, November 16, 1989. - P.11.

7. Zone and Site Information [Электронный ресурс]. - Режим доступа: http://ita-web.ita.doc.gov/FTZ/OFISLogin.nsf (дата обращения-20.10.2015).

8. th Annual Report of the Foreign-Trade Zones Board to the Congress of the United States [Электронный ресурс]. - Режим доступа: http://enforcement.trade.gov/ftzpage/annualreport/ar-2014.pdf (дата обращения-20.10.2015).

9. Bolle M.J., Williams B.R. U.S. Foreign-Trade Zones: Background and Issues for Congress. November 12, 2013. - Р. 1. [Электронный ресурс]. - Режим доступа: http://fas.org/sgp/crs/misc/R42686.pdf (дата обращения: 20.10.2015).

10. The Foreign-Trade Zones Act 1934. [Электронный ресурс]. - Режим доступа: http://enforcement.trade.gov/ftzpage/ grantee/regs.html (дата обращения-20.10.2015).

11. Горян Э.В. Перспективы создания особой экономической зоны «свободный порт Владивостока»: сравнительноправовой анализ // Право и политика. - 2015.-№ 4.-C.467-475. - C. 468. DOI: 10.7256/1811-9018.2015.4.14786

12. FTZ Board regulations (19 U.S.C. 81a-81u). [Электронный ресурс]. - Режим доступа: http://enforcement.trade.gov/ ftzpage/grantee/regs.html (дата обращения-20.10.2015)

13. Code of Federal Regulations, 19 CFR 146-FTZ Regulations. [Электронный ресурс]. - Режим доступа: http://www.gpo. gov/fdsys/granule/CFR-2012-title19-vol2/CFR-2012-title19-vol2-part146 (дата обращения - 20.10.2015)

14. Article 1, Section 8, Clause 3, U.S. Constitution [Электронный ресурс]. - Режим доступа: http://www.senate.gov/civics/ constitution_item/constitution.htm (дата обращения-20.10.2015)

15. Article 1, Section 10, Clause 2, U.S. Constitution [Электронный ресурс]. - Режим доступа: http://www.senate.gov/ civics/constitution_item/constitution.htm (дата обращения-20.10.2015)

16. Deer Park Independent School District v. Harris County Appraisal Dist., 132 F. 3d 1095 (5th Cir. 1998) cert denied, 118 S. Ct. 2343, 141 L. Ed 2d 714 [Электронный ресурс]. - Режим доступа: http://caselaw.findlaw.com/us-5th-circuit/1200279. html (дата обращения-20.10.2015)

17. Павлов П.В. Эволюция правового регулирования института свободных экономических зон в России и за рубежом // Журнал зарубежного законодательства и сравнительного правоведения / Journal of foreighn legislation and comparative law. - 2011. - 4. - C. 81 - 91.

18. Волокитина Ю.В. Порядок реализации государственной инновационной политики путём использования правового потенциала отечественных ОЭЗ // Тренды и управление. - 2013. - 2. - C. 236 - 240. DOI: 10.7256/23079118.2013.2.5166.

19. Балаева Д.А. К вопросу создания особых экономических зон в приграничных районах РФ. // Налоги и налогообложение. - 2014. - 12. - С. 1092 - 1096. DOI: 10.7256/1812-8688.2014.12.12512.

\section{References (transliterated):}

1. Goryan E.V. Stanovlenie instituta podzony osoboi ekonomicheskoi zony v SShA // Administrativnoe i munitsipal'noe pravo. - 2015.-№ 10.-S.1029-1038. - S. 1030. DOI: 10.7256/1999-2807.2015.10.16480

2. Engman M., Onodera O., Pinali E. Export Processing Zones: Past and Future Role in Trade and Development // OECD Trade Policy Papers 53, OECD Publishing [Elektronnyi resurs]. - Rezhim dostupa: https://ideas.repec.org/p/oec/traaab/53-en. html (data obrashcheniya: 20.10.2015)

3. $\quad$ Diamond W.H., Diamond D.B., Tax-Free Trade Zones of the World, Unz \& Co., 1997. - R.33.

4. Yarbrough B.V., Yarbrough R.M. The World Economy: Trade and Finance.-Harcourt Brace, 1991. - R. 368.

5. GAO, Foreign-Trade Zones Growth Primarily Benefits Users Who Import for Domestic Commerce, GAO/GGD 84-52, March 2, 1984, p. 12 [Elektronnyi resurs]. - Rezhim dostupa: http://gao.justia.com/department-of-commerce/1984/3/foreigntrade-zone-growth-primarily-benefits-users-who-import-for-domestic-commerce-ggd-84-52/GGD-84-52-full-report. pdf (data obrashcheniya-20.10.2015)

6. U.S. Congress, House, Committee on Government Operations, Foreign-Trade Zones (FTZ) Program Needs Restructuring, House Report 101-363, November 16, 1989. - R.11.

7. Zone and Site Information [Elektronnyi resurs]. - Rezhim dostupa: http://ita-web.ita.doc.gov/FTZ/OFISLogin.nsf (data obrashcheniya-20.10.2015).

8. th Annual Report of the Foreign-Trade Zones Board to the Congress of the United States [Elektronnyi resurs]. - Rezhim dostupa: http://enforcement.trade.gov/ftzpage/annualreport/ar-2014.pdf (data obrashcheniya-20.10.2015). 


\section{Административное и муниципальное право 11 (95) • 2015}

9. Bolle M.J., Williams B.R. U.S. Foreign-Trade Zones: Background and Issues for Congress. November 12, 2013. - R. 1. [Elektronnyi resurs]. - Rezhim dostupa: http://fas.org/sgp/crs/misc/R42686.pdf (data obrashcheniya: 20.10.2015).

10. The Foreign-Trade Zones Act 1934. [Elektronnyi resurs]. - Rezhim dostupa: http://enforcement.trade.gov/ftzpage/ grantee/regs.html (data obrashcheniya-20.10.2015).

11. Goryan E.V. Perspektivy sozdaniya osoboi ekonomicheskoi zony «svobodnyi port Vladivostoka»: sravnitel'no-pravovoi analiz // Pravo i politika. - 2015.-№ 4.-S.467-475. - S. 468. DOI: 10.7256/1811-9018.2015.4.14786

12. FTZ Board regulations (19 U.S.C. 81a-81u). [Elektronnyi resurs]. - Rezhim dostupa: http://enforcement.trade.gov/ ftzpage/grantee/regs.html (data obrashcheniya-20.10.2015)

13. Code of Federal Regulations, 19 CFR 146-FTZ Regulations. [Elektronnyi resurs]. - Rezhim dostupa: http://www.gpo.gov/ fdsys/granule/CFR-2012-title19-vol2/CFR-2012-title19-vol2-part146 (data obrashcheniya - 20.10.2015)

14. Article 1, Section 8, Clause 3, U.S. Constitution [Elektronnyi resurs]. - Rezhim dostupa: http://www.senate.gov/civics/ constitution_item/constitution.htm (data obrashcheniya-20.10.2015)

15. Article 1, Section 10, Clause 2, U.S. Constitution [Elektronnyi resurs]. - Rezhim dostupa: http://www.senate.gov/civics/ constitution_item/constitution.htm (data obrashcheniya-20.10.2015)

16. Deer Park Independent School District v. Harris County Appraisal Dist., 132 F. 3d 1095 (5th Cir. 1998) cert denied, 118 S. Ct. 2343, 141 L. Ed 2d 714 [Elektronnyi resurs]. - Rezhim dostupa: http://caselaw.findlaw.com/us-5th-circuit/1200279. html (data obrashcheniya-20.10.2015)

17. Pavlov P.V. Evolyutsiya pravovogo regulirovaniya instituta svobodnykh ekonomicheskikh zon v Rossii i za rubezhom // Zhurnal zarubezhnogo zakonodatel'stva i sravnitel'nogo pravovedeniya / Journal of foreighn legislation and comparative law. - 2011. - 4. - C. 81 - 91.

18. Volokitina Yu.V. Poryadok realizatsii gosudarstvennoi innovatsionnoi politiki putem ispol'zovaniya pravovogo potentsiala otechestvennykh OEZ // Trendy i upravlenie. - 2013. - 2. - C. 236 - 240. DOI: 10.7256/2307-9118.2013.2.5166.

19. Balaeva D.A. K voprosu sozdaniya osobykh ekonomicheskikh zon v prigranichnykh raionakh RF. // Nalogi $\mathrm{i}$ nalogooblozhenie. - 2014. - 12. - C. 1092 - 1096. DOI: 10.7256/1812-8688.2014.12.12512. 